\title{
Internally Stressed Polymeric Composite/Metal Cylinders: Manufacturing, Testing and Quality Verifying by Simplified Procedure
}

\author{
Jovan Radulović ${ }^{1)}$ \\ Nikša Žegarac ${ }^{1)}$
}

\begin{abstract}
In this paper the details about manufacturing of multilayer cylinders consisting of metal liner (obtained by standard machining procedures) and polymeric composite material (produced by filament winding technology) are presented. For multilayer cylinders manufacturing three types of steel liner (each liner type has three different wall thicknesses) are used. Glass fibers impregnated with polyester resin were wound at the outer surface of the mentioned nine liners and so the manufactured multilayer tubes were exposed to the action of internal hydraulic pressure with measurement of deformations in radial direction.

Two groups of the results, obtained during hydraulic testing of multilayer cylinders, were presented: one group represents elastic characteristics, i.e. the properties of the examined tubes at the elastic limit, and another group represents the final properties, i.e. the characteristics of the tested tubes at the moment of burst.

Calculation of the pressure at the elastic limit, by a simplified procedure, was done. By comparing the value of experimentally tested pressure at the elastic limit and the value of calculated pressure at the elastic limit, it was concluded that there is a good agremeent between these two data. Values of experimentally tested radial deformations at the elastic limit of external surface of multilayer tubes and values of this parameter obtained by calculation of simplified model, are, also, meaningfully approximate.

Based on the experimental data, an influence of a pathway from the lower outside liner diameter to higher outside liner diameter was established, and, also, an influence of liner wall thickness on characteristics of multilayer tubes, which were exposed to the action of internal hydraulic pressure.

Based on the introduced parameter hydraulic burst pressure/mass ratio, it was concluded that a higher presence of polymer composite material has positive influence on hydraulic burst pressure (increasing) and mass (decreasing) of the mentioned multilayer tubes.
\end{abstract}

Key words: polymeric materials, composite materials, cylinder, tube, multilayer element, glass fiber, polyester resin, filament winding, hydraulic pressure, elastic characteristics, elastic limit.

\section{Introduction}

$\mathrm{M}$ AKING things or manufacturing has been an essential activity of human civilizations even before recorded history. Manufacturing is an application of physical and chemical processes to alter the geometry, properties and/or appearance of a given initial material in order to make parts and products [1].

Materials are the basic elements of all natural and manmade products. Most engineering materials can be classified into one of three basic categories: (1) metals, (2) ceramics and (3) polymers. Recently, composites are added as the fourth engineering material. Classification of four engineering materials is shown in Fig.1 [1].

Metallic cylinders are often exposed to the influence of pressure, caused by fliud action inside this part, during a shorter or longer period of time. The disadvantage of these elements is a great mass, because of a high density of materials (for example steel has $7,8 \mathrm{~g} / \mathrm{cm}^{3}$ density). Polymeric composite tubes, which can withstand high internal loading, are characterized with considerably smaller density $\left(2,0 \mathrm{~g} / \mathrm{cm}^{3}\right)$, so a mass of this part is appreciably less. Product, which includes a cylinder (consisting of internal metallic and external polymeric composite tubes) stressed with important level of internal pressure, would have a smaller mass, higher mobility and shorter preparation time to the moment of action.

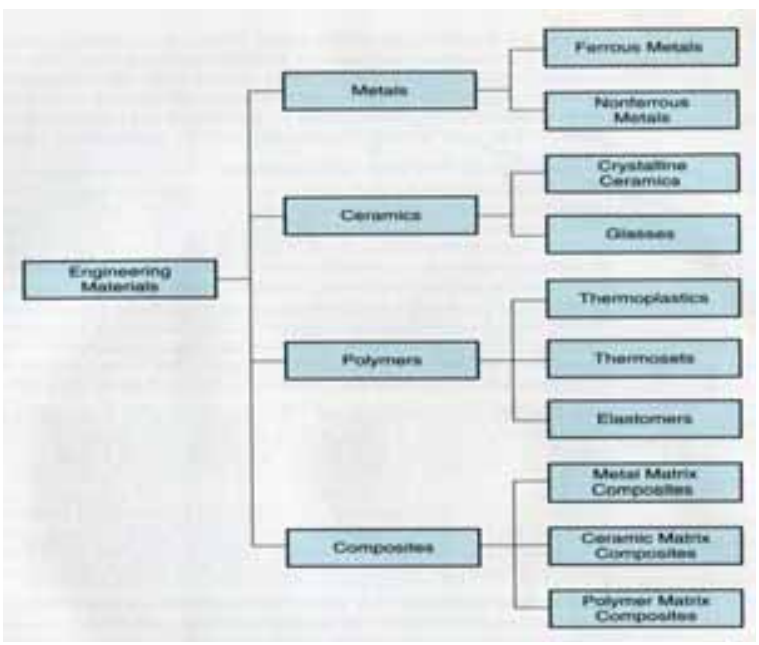

Figure 1. Classification of four engineering materials [1]

\footnotetext{
1) Military Technical Institute (VTI), Ratka Resanovića 1, 11132 Belgrade, SERBIA

Correspondence to: Jovan Radulović; e-mail: jovan.r.radulovic@gmail.com
} 
Tai and others evaluated the behavior and energy absorbing capacity of cylindrical metal tubes that are externally wrapped with carbon- and glass fiber-reinforced composite. The results demonstrate that a wrapped composite tubes can be utilized effectively to enhance the crushing characteristics and energy absorbing capacity of the tubes. Increasing the thickness of the composite increases the mean force and the specific energy absorption under both static and dynamic crushing [2].

Bambach studied the axial capacity and crushing of thinwalled metal, composite fiber-epoxy and composite metalfiber tubes and utilized a specific system to determine the buckling behavior [3].

Choqueuse et el. manufactured steel-composite tubes and tested the behavior of such structures under hydrostatic pressure. They used a composite material layer to increase the safety factor of a metallic tube in order to reach a satisfactory safety limit and to significantly reduce the weight of the ensemble [4].

Tzeng J.T. has been investigated the fracture behavior of a composite cylinder $2,5 \mathrm{~m}$ long, consisting of the steel liner and overwrapped graphite epoxy composite, with a constant walls thickness. The stress wave with a high magnitude, while short in duration, might not cause a structural failure immediately; however, it could accelerate the propagation in the cylinder with an initial imperfection and shorten fatigue life of the cylinders. The fracture mechanism induced by dynamic amplification effects is especially critical for composite overwrapped cylinders because of the multimaterial construction, thermal degradation in material properties and a design goal that is inherent in lightweight gun barrel applications [5].

It has been stated that a multilayer tube, consisting of three parts (the first, external is a glass fiber-reinforced epoxy composite; the second, middle is a high-strength stainless steel and the third, internal is again a glass fiberreinforced epoxy composite), can withstand extremely high pressure in the environments exposed to corrosion. In addition to its good mechanical properties, this product is, also, claimed to be cheaper to manufacture than stainless steel tubes, with a service life of at least 30 years compared with an estimated six months to three years for stainless steel tubes in similar corrosion conditions [6].

In this paper the details about manufacturing of multilayer cylinders consisting of thin steel tube (obtained by standard machining procedures) and polymeric composite material (produced by filament winding technology) are presented. For multilayer tubes manufacturing three types of thin steel tube (in further text: liner) are used, which differ one from another in a pathway from a lower outside diameter to a higher diameter. Each liner type has three different wall thicknesses at the position of a lower outside diameter.

All tested tubes, obtained by filament winding of glass fiber impregnated by a polyester resin system over metal liner, were exposed to the influence of internal hydraulic pressure. The values of radial deformations were recorded during the whole process of exposing the mentioned test tubes to the action of internal hydraulic pressure, i.e. from the initial moment to the burst moment. The corresponding values of internal hydraulic pressure were recorded, as well.

Based on the registered data, diagrams which show the dependence of radial deformations versus internal hydraulic pressure during the whole testing process were done.

The elastic characteristics of the examined tubes were obtained from the diagram of the dependence of internal hydraulic pressure versus radial deformations. The elastic characteristics, i.e. radial deformations and the appropriate internal hydraulic pressure of the mentioned test tubes at the elastic limit were obtained from the linear portion of the mentioned diagrams.

The final characteristics of the examined multilayer tubes, i.e. data for radial deformations and internal hydraulic pressure at the burst moment were, also, presented.

Calculation of the pressure at the elastic limit, by a simplified procedure, was done. By comparing the value of experimentally tested pressure at the elastic limit and the value of calculated pressure at the elastic limit, it was concluded that there is a good agreement between these two data. Experimentally determined radial deformations at the elastic limit and the values of this parameter, obtained by calculation procedure are, also, close to each other.

Based on the experimental data, the influence of a pathway from a lower outside liner diameter to a higher outside liner diameter was established, and, also, the influence of liner wall thickness on characteristics of multilayer tubes, which were exposed to the influence of internal hydraulic pressure.

Based on the introduced parameter hydraulic burst pressure/mass ratio, it has been concluded that a higher presence of polymer composite material has positive influence on hydraulic burst pressure (increasing) and mass (decreasing) of mentioned multilayer tube.

\section{Experimental part}

All metallic liners were produced using nickelchromium-molybdenum steel alloy defined as 35 NCD 16 in ANFOR standard, and as 36NiCRMo 16 in EN 10083-1 standard, produced by metal material manufacturer Auber \& Duval, France. Three types of liner are used for multilayer tubes manufacturing. The mentioned three types of steel liner are presented in Figures 2-4, by order of succession.

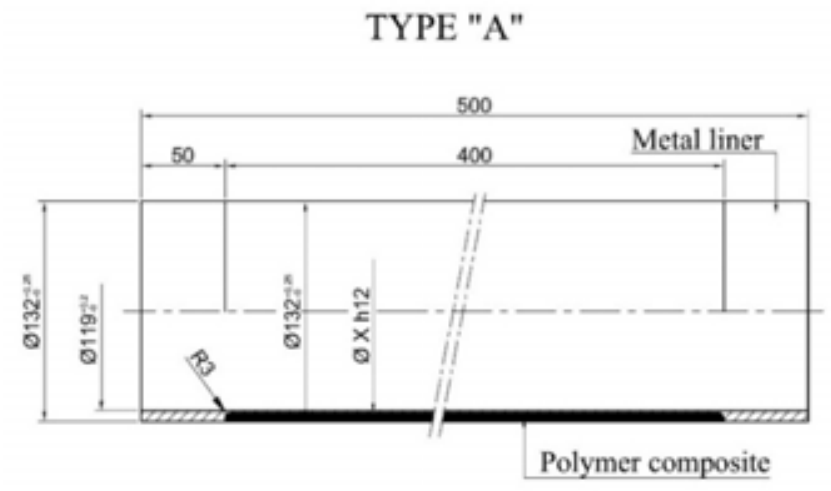

Figure 2. Metal liner of A

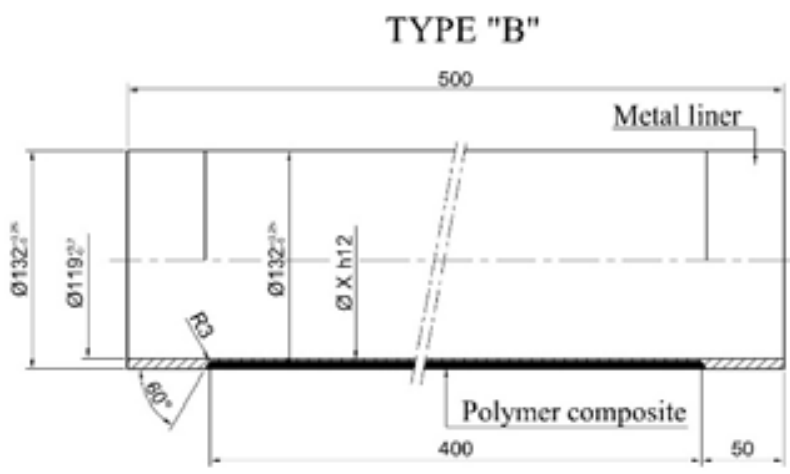

Figure 3. Metal liner of B type 


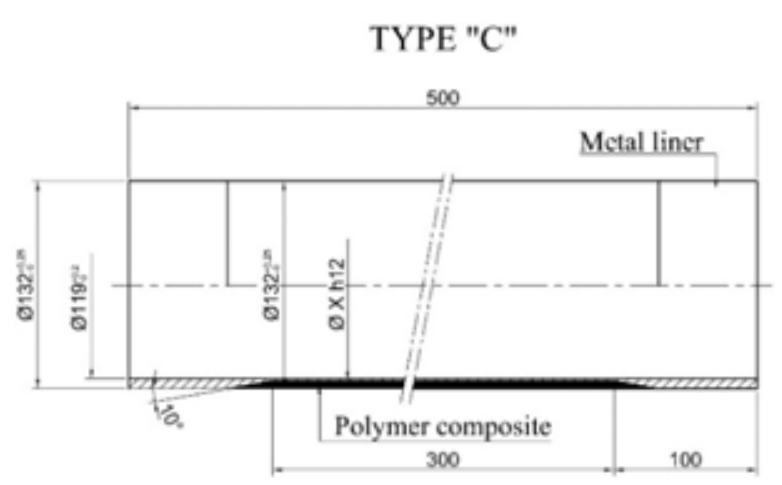

Figure 4. Metal liner of $\mathrm{C}$ type

As can be seen in Fig.2, at the liner of A type, a pathway from a lower outside liner diameter to a higher outside liner diameter is acute and reaches almost $90^{\circ}$ angle. At the liner of B type (Fig.3), a pathway is less acute and reaches $60^{\circ}$ angle. The liner of $\mathrm{C}$ type (Fig.4) has a slight pathway and reaches $10^{\circ}$ angle.

Internal diameter of all liners, no matter to type, is $119 \mathrm{~mm}$. Outer diameter of all multilayer tubes steel liner/polymer composite is $132 \mathrm{~mm}$.

Smaller outside liner diameter is labeled as diameter $\mathrm{X}$ in Figures 2-4, and has $122 \mathrm{~mm}, 124 \mathrm{~mm}$ and $126 \mathrm{~mm}$ values, respectively.

Liner with the internal diameter $119 \mathrm{~mm}$ and smaller outside diameter $122 \mathrm{~mm}$ has a wall thickness $1.5 \mathrm{~mm}$.

Liner with the internal diameter $119 \mathrm{~mm}$ and smaller outside diameter $124 \mathrm{~mm}$ has a wall thickness $2.5 \mathrm{~mm}$.

Liner with the internal diameter $119 \mathrm{~mm}$ and smaller outside diameter $126 \mathrm{~mm}$ has a wall thickness $3.5 \mathrm{~mm}$.

The "composites" concept is not a human invention. Wood is a natural composite material consisting of one species of polymer (cellulose fibres) in a resinous matrix of another polymer (the polysaccharide lignin). Composite material is composed of two or more distinct phases (matrix phase and dispersed phase) and has bulk properties significantly different from those of any of the constituents. It is important to point out that separate constituents in composites act together to provide the necessary mechanical strength or stiffness to the composite part [7].

One of the composite materials production technology increasingly used is the filament winding technology. Filament wound polymeric composites consist of a reinforcing agent and an impregnating agent. Composite materials in which matrix phase or impregnating agent is polymer are called polymer based composites.

The filament winding technology, in brief, consists of winding fiber reinforcing agents previously impregnated by a resin impregnating system on a liner or on a mandrel, curing wound structure and removing the cured product from the tool [8].

The composite parts of multilayer steel liner/polymer composite tubes were obtained by winding a glass roving mark R 2117 impregnated by a polyester resin system mark DUGAPOL H 230 over an apropriate metallic liner mounted on a cylindrical mandrel.

A glass roving mark $\mathrm{R} 2117$, made by the glass fibre manufacturer "ETEX", Serbia, belongs to calcium alumino borosilicate glass products with low alkali oxides content. Composites reinforced with this glass fiber (so called E-glass) posses good tensile and compressive strength and stifness, good electrical properties and relatively low price $[9,10]$.

The used polyester resin system consists of polyester resin mark DUGAPOL H 230, a hardener N (the 50\% solution of methyl ethyl keton peroxide in toluene) and an accelerator $\mathrm{N}$ (the $6 \%$ solution of cobalt naphtenate in dimethyl phtalate), made by the polyester resin manufacturer "DUGA", Serbia, with the addittion of an inhibitor TBC, produced by the chemical producer AKZO, Netherland. Resin DUGAPOL H 230 belongs to unsaturated polyester resins produced by esterification reaction of propylene glicol and maleic acid anhydride and phtalic acid anhydride. Non-reinforced polyester resin has a good balance of mechanical, electrical and chemical resistance properties. Fiber reinforced polyester material retain mentioned properties of neat polyester resins at higher level (especially mechanical characteristics) and posses additional dimensional stability [11].

The winding angle is an angle which the reinforcing agent (fiber) forms regarding the longitudinal axis of the product. Winding angle for composite part is $90^{\circ}$. This part is produced by the filament winding technology using the PLASTEX type PLA 500 machine, made by the machine manufacturer PLASTEX-MANUHRINE, France.

The wound tubes were exposed to the cure schedule proposed by the resin system manufacturer $\left(2 \mathrm{~h}\right.$ at $\left.80^{\circ} \mathrm{C}\right)$.

A metal liner assembly/cured composite part was removed from the mandrel and by the machining process only a layer of pure resin was removed from the outer surface of composite tubes, so that the final layer of glass fiber remained undamaged. By described manner all outer diameters of multilayer tubes were realized, according to answerable dimensional requirements.

Multilayer tube steel liner/polymer composite, which contains steel liner of A type with the wall thickness of 1.5 $\mathrm{mm}$ and polymer composite part with radial wound glass fiber impregnated with polyester resin, for the purpose of writing this paper, was labeled as A15-R.

Multilayer tube steel liner/polymer composite,which contains liner of A type with the wall thickness of $2.5 \mathrm{~mm}$ and polymer composite part with radial wound glass fiber impregnated with polyester resin, in this paper, was labeled as A25-R.

Multilayer tube steel liner/polymer composite, which contains liner of A type with the wall thickness of $3.5 \mathrm{~mm}$ and polymer composite part with radial wound glass fiber impregnated with polyester resin, for a purpose of this paper, was labeled as A35-R.

The same designation system referred to liner of $\mathrm{B}$ type (B15-R, B25-R, B35-R) and liner of C type (C15-R, C25-R, C35-R).

The wall thickness of wound composite parts at multilayer tubes of A15-R, B15-R and C15-R label is 5 $\mathrm{mm}$. The multilayer tubes of A25-R, B25-R and C25-R label posses $4 \mathrm{~mm}$ thick wound composite parts. The wall thickness of wound composite parts at multilayer tubes of A35-R, B35-R and C35-R label is $3 \mathrm{~mm}$.

Elastic and final properties of the multilayer test tubes were experimentally determined by a device for monotonic increasing hydraulic pressure of $150 \mathrm{MPa}$ range, produced by the hydraulic equipment manufacturer WALTER \& BAI, Germany, along with the protection equipment and the specific tool for testing the tubes hydraulic burst pressure.

The internal hydraulic pressure was measured with a piezoelectric converter of $601 \mathrm{H}$ pressure label and of 100 $\mathrm{MPa}$ range, manufactured by the measuring device manufacturer KISTLER, Germany.

Two one-axis strain gauges HBB 10/120 LA 11 manufactured by the strain gauges manufacturer HOTTINGER BALDWIN MESSTECHNIK, Gmbh, Germany, were glued to the outer surface of the test tube 
for hydraulic investigation using the adhesive X 60 produced by same manufacturer. Mentioned two one-axis strain gauges were positioned in the middle of the tube length, one opposite to another, transversal to the longitudinal axis of the tubes in order to record radial deformations.

A digital oscilloscope NICOLET 4094 B with additional equipment, produced by the measuring equipment manufacturer NICOLET INSTRUMENTS, USA, was used for the simultaneous detection of the internal hydraulic pressure and radial deformation.

Basic characteristic of the multilayer tube is the internal pressure value to which it can be exposed without plastic deformation in any part of the tube. Concretely, this multilayer tube consists of internal steel isotropic (has the same properties in both directions) tube and external composite anisotropic (certain properties in one direction and other properties in another direction) tube. Due to the fact that fibers are wound in a direction in which the highest stress is acting and because of a linear dependence between stress and deformation at composite materials, an aproximation acceptable for simplified calculation, will be done. Multilayer tube will be treated as it consists of two isotropic tubes, one hooked to another, without clamping force, exposed to internal pressure.

During an action of internal pressure $\left(p_{1}\right)$ on a multilayer tube, deformation of external surface of internal steel tube is equal to the deformation of inside surface of outside composite tube.

Deformation of external surface of internal metal tube, according to the shell theory, is:

$$
\varepsilon_{t i}=\frac{p_{1}\left(r_{1}+r_{2}\right)}{2 E_{1}\left(r_{2}-r_{1}\right)}-\frac{p_{2}\left(r_{1}+r_{2}\right)}{2 E_{1}\left(r_{2}-r_{1}\right)}
$$

where:

$r_{1}$ - internal radius of metal tube,

$r_{2}$ - external radius of metal tube,

$E_{1}$ - modul of elasticity of metal tube,

$p_{1}$ - pressure at an internal surface of the metal tube and

$p_{2}$ - pressure at an external surface of the metal tube.

Deformation of inside surface of outside composite tube, according to the shell theory, is:

$$
\varepsilon_{t 2}=\frac{1}{E_{2}} \frac{2}{3} p_{2} \frac{2 r_{3}^{2}+r_{2}^{2}}{\left(r_{3}^{2}-r_{2}^{2}\right)}
$$

where:

$r_{3} \quad$ - outside radius of composite tube and

$E_{2} \quad$ - modul of elasticity of composite tube.

As long as $\varepsilon_{t 1}=\varepsilon_{t 2}$, from Eq.(1) and Eq.(2), it comes out that:

$$
p_{2}=\frac{r_{1}+r_{2}}{2 E_{1}\left(r_{2}-r_{1}\right)}\left[\frac{\left(r_{1}+r_{2}\right)}{2 E_{1}\left(r_{2}-r_{1}\right)}+p_{2} \frac{2}{3} \frac{1}{E_{2}} \frac{2\left(r_{2}^{2}+r_{2}^{2}\right)}{\left(r_{2}^{2}-r_{2}^{2}\right)}\right]
$$

Reduced stress $(\sigma)$, according to octaedar stresses hypothesis, is:

$$
\sigma=\sqrt{\frac{1}{2}}\left[\left(\sigma_{1}-\sigma_{2}\right)^{2}+\left(\sigma_{2}-\sigma_{3}\right)^{2}+\left(\sigma_{3}-\sigma_{1}\right)^{2}\right]
$$

where:

$\sigma_{1}=\sigma_{t} \quad$ - stress in tangential direction,

$\sigma_{2}=\sigma_{r} \quad$ - stress in radial direction and

$\sigma_{3}=\sigma_{z} \quad$ - stress in axial direction.

Stress in tangential direction at an internal surface of the metal tube $\left(\sigma_{1}=\sigma_{t}\right)$, according to the shell theory (thickness is small versus other dimensions), is:

$$
\sigma_{1}=\sigma_{t}=\left(p-p_{2}\right)\left[\frac{\left(r_{1}+r_{2}\right)}{2\left(r_{2}-r_{1}\right)}\right]
$$

Stress in radial direction, $\left(\sigma_{2}=\sigma_{r}\right)$, according to the shell theory, is :

$$
\sigma_{2}-\sigma_{r}=0
$$

Stress in axial direction $\left(\sigma_{3}=\sigma_{z}\right)$, according to the shell theory, is:

$$
\sigma_{3}=\sigma_{z}=\left(p_{1}-p_{2}\right)\left[\frac{\left(r_{1}+r_{2}\right)}{4\left(r_{2}-r_{1}\right)}\right]
$$

Reduced stress at an internal surface of the metal tube $\left(\sigma_{1}\right)$, is obtained by incorporation of Eq.(5-7) into Eq.(4) and it comes out that :

$$
\sigma_{t}=\left(p_{1}-p_{2}\right)\left[\frac{\left(r_{2}+r_{1}\right) \sqrt{3}}{4\left(r_{2}-r_{1}\right)}\right]
$$

Putting Eq.(3) into Eq.(8), replacing $\sigma_{1}$ with metal material characteristics at the elastic limit and introducing safety factor $\eta$, the highest value of pressure that causes no plastic deformation of metal tube $\left(p_{I}\right)$ is obtained:

$$
p_{1}=\frac{1}{\eta}\left\{\frac{\sigma_{0.2 t}\left[\frac{\left(r_{1}+r_{2}\right)}{2 E_{1}\left(r_{2}-r_{1}\right)}+\frac{2\left(r_{3}^{2}+r_{2}^{2}\right)}{3 E_{2}\left(r_{3}^{2}-r_{2}^{2}\right)}\right]}{\frac{\left(r_{2}+r_{1}\right) 2\left(2 r_{2}^{2}-r_{2}^{2}\right) \sqrt{3}}{b\left(r_{2}-r_{1}\right) E_{2} 3\left(r_{3}^{2}-r_{2}^{2}\right)}}\right\}
$$

Stresses in tangential, radial and axial directions at the inside surface of outside composite tube, according to Lame equations, are:

$$
\begin{gathered}
\sigma_{1}=\sigma_{t}=p_{2}\left[\frac{\left(r_{3}^{2}+r_{2}^{2}\right)}{\left(r_{3}^{2}-r_{2}^{2}\right)}\right] \\
\sigma_{2}=\sigma_{r}=p_{2} \\
\sigma_{3}=\sigma_{z}=p_{2}\left[\frac{r_{2}^{2}}{\left(r_{3}^{2}-r_{2}^{2}\right)}\right]
\end{gathered}
$$

By putting expresions (10), (11) and (12) into Eq.(4), a reduced stress at inside surface of composite tube $\left(\sigma_{I I}\right)$ is obtained:

$$
\sigma_{I I}=p_{2}\left[\frac{\sqrt{2 r_{2}^{b}+r_{3}^{b}-2 r_{3}^{2} r_{2}^{2}}}{\left(r_{3}^{2}-r_{2}^{2}\right)}\right]
$$

By putting Eq.(3) into Eq.(13), replacing $\sigma_{I I}$ with composite material properties at the elastic limit and introducing safety factor $\eta$, the highest pressure value that causes no plastic deformation of composite tube $\left(p_{I I}\right)$ is obtained:

$$
p_{I I}=\frac{1}{\eta}\left\{\frac{\sigma_{0.2 t}\left(r_{3}^{2}-r_{2}^{2}\right)\left[\frac{\left(r_{1}+r_{2}\right)}{\left(r_{1}+r_{2}\right)}+\frac{12^{2}\left(r_{3}^{2}+r_{2}^{2}\right)}{E_{2} 3\left(r_{3}^{2}-r_{2}^{2}\right)}\right]}{\frac{\left(r_{1}+r_{2}\right) \sqrt{2 r_{2}^{b}+r_{3}^{b}-2 r_{3}^{2} r_{2}^{2}}}{2 E_{1}\left(r_{2}-r_{1}\right)}}\right\}
$$


Based on Lame equations, deformation of the outside surface of composite tube $\left(\varepsilon_{I}\right)$ is:

$$
\varepsilon_{t}=\frac{p_{2}}{E_{2}} \frac{2 r_{2}^{2}}{\left(r_{3}^{2}-r_{2}^{2}\right)}
$$

By putting expresion (3) into Eq.(15), $\left(\varepsilon_{\mathrm{I}}\right)$ is obtained :

$$
\varepsilon_{t}=\frac{1}{E_{2}} \frac{2 r_{2}^{2}}{\left(r_{3}^{2}-r_{2}^{2}\right)}\left\{\frac{\frac{\left(r_{1}+r_{2}\right)}{2 E_{1}\left(r_{2}-r_{1}\right)}}{\frac{\left(r_{1}+r_{2}\right)}{2 E_{1}\left(r_{2}-r_{1}\right)}+\frac{2\left(2\left(r_{3}^{2}+r_{2}^{2}\right)\right)}{3 E_{2}\left(r_{3}^{2}-r_{2}^{2}\right)}}\right\}
$$

By putting appropriate data for mentioned materials in Eq.(16) and taking values of corresponding pressures, deformations of the outer surface of multalayer tubes are calculated and presented in figures.

\section{Results}

In the stress-strain diagrams of most materials, two regions can be observed:

- region in which material returns to its original state after stress removal, i.e. elastic region of materials, and

- region in which material does not return to its original state after stress removal, i.e. plastic region of materials.

The point up to which a material exhibits elastic behaviour is called the elastic limit $[12,13]$.

It is well known that a linear dependence on a stressstrain diagram denotes the elastic region of materials. By analogy, a point on the internal hydraulic pressure-radial deformations diagram dependence, at which a change of slope occurs, denotes the elastic limit of test tubes.

The values of radial deformation 1 and radial deformation 2 are obtained by two mentioned one-axis strain gauges and an arithmetic mean value of radial deformation is based on two single radial deformation values.

Data, obtained during the examination process, i.e. internal hydraulic pressure and radial deformations, caused by the appropriate values of this pressure, are shown in figures.

The arithmetic mean values of the radial deformations versus internal hydraulic pressure for test tubes A15-R, A25-R and A35-R are presented in Fig.5.

The arithmetic mean values of the radial deformations versus internal hydraulic pressure for test tubes B15-R, B25-R and B35-R are presented in Fig.6.

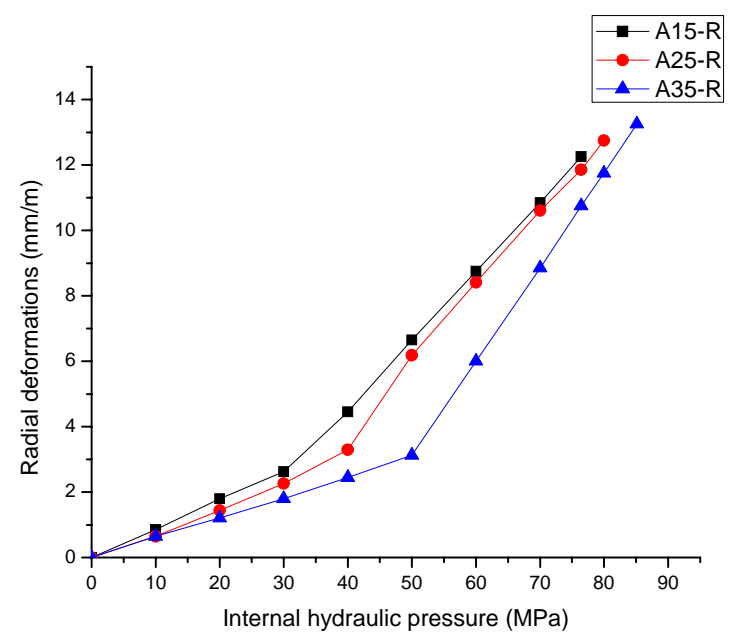

Figure 5. Radial deformations versus internal hydraulic pressure for test tubes A15-R, A25-R and A35-R

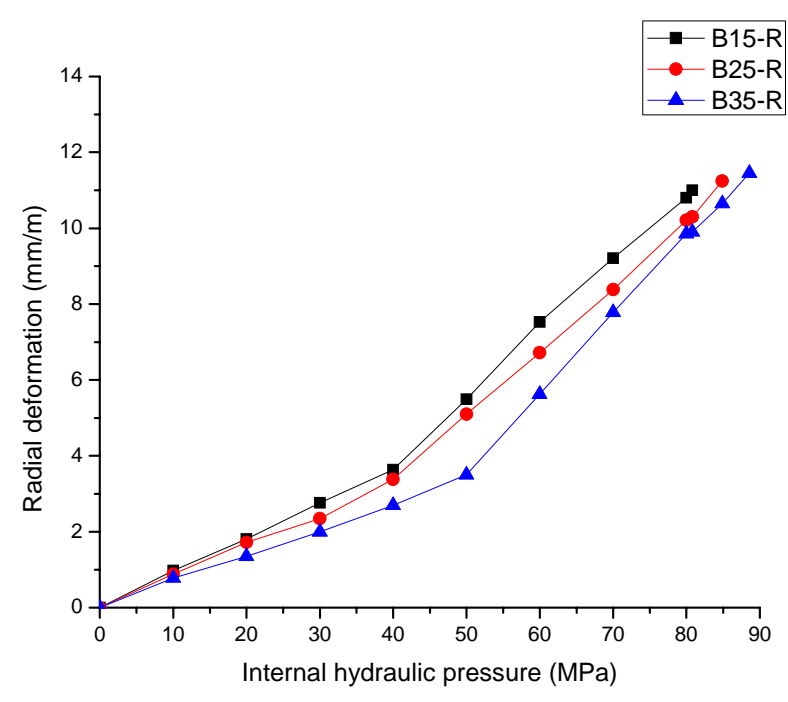

Figure 6. Radial deformations versus internal pressure for test tubes B15$\mathrm{R}, \mathrm{B} 25-\mathrm{R}$ and B35-R

The arithmetic mean values of the radial deformations versus internal hydraulic pressure for test tubes, C15-R, C25-R and C35-R are presented in Fig.7.

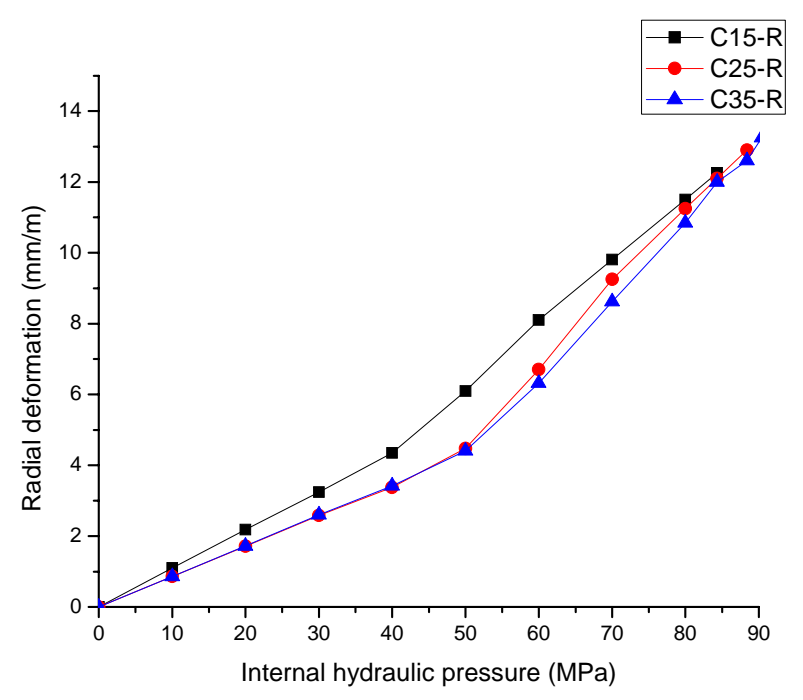

Figure 7. Radial deformations versus internal hydraulic pressure for test tubes C15-R, C25-R and C35-R

Based on the experimentally obtained data, presented in Figures 5-7, values of the internal hydraulic pressure at the elastic limit for multilayer tubes metal liner/polymer composite (in the further text: experiment pressure at the e.1.) are estimated. These data are presented in Table 1.

Table 1. Experimentally obtained values of internal hydraulic pressure at the elastic limit for multilayer metal liner/polymer composite tubes

\begin{tabular}{||c|c|c|c|c|c|c|c|c|c||}
\hline $\begin{array}{c}\text { Multilayer } \\
\text { tube label }\end{array}$ & A15-R & A25-R & A35-R & B15-R & B25-R & B35-R & C15-R & C25-R & C35-R \\
\hline \hline $\begin{array}{c}\text { Experiment } \\
\text { pressure at } \\
\text { e.l. }(\mathrm{MPa})\end{array}$ & 30 & $\begin{array}{c}\text { From } \\
35 \text { to } \\
40\end{array}$ & 50 & 30 & $\begin{array}{c}\text { From } \\
\begin{array}{c}35 \text { to } \\
40\end{array}\end{array}$ & 50 & 30 & $\begin{array}{c}\text { From } \\
40 \text { to } \\
45\end{array}$ & 50 \\
\hline
\end{tabular}

Values of the internal hydraulic pressure at the elastic limit of multilayer tubes metal liner/polymer composite, obtained by calculation procedure of a simplified model (in the further text: calculated pressure at the e.1.), are presented in Table 2. 
Table 2. Calculated values of the internal hydraulic pressure at the elastic limit of multilayer tubes metal liner/polymer composite

\begin{tabular}{|c|c|c|c|c|c|c|c|c|c||}
\hline $\begin{array}{c}\text { Multilayer } \\
\text { tube label }\end{array}$ & A15-R & A25-R & A35-R & B15-R & B25-R & B35-R & C15-R & C25-R & C35-R \\
\hline \hline $\begin{array}{c}\text { Calculated } \\
\text { pressure at } \\
\text { e.l. (MPa) }\end{array}$ & 37 & 46 & 55 & 37 & 46 & 55 & 37 & 46 & 55 \\
\hline
\end{tabular}

By comparasion of the experimentally determined values of the internal hydraulic pressure at the elastic limit and values of the internal hydraulic pressure at the elastic limit, obtained by the mentioned calculation of a simplified model, a good agreement of these two parameters for all multilayer tubes metal liner/polymer composite can be seen.

Radial deformations values at the elastic limit, obtained by the mentioned calculation procedure for multilayer tubes, are presented in diagram form in figures.

Values of the experimentally tested radial deformation at the elastic limit (in the further text for figure presentation: by experiment) and the radial deformation at the elastic limit obtained by the mentioned calculation of a simplified model (in the further text for figure presentation: by model) for multilayer tube of A15-R, A25-R and A35-R label are presented in Fig.8. Values of the radial deformation at the elastic limit by experiment and the radial deformation at the elastic limit by model for multilayer tube of B15-R, B25-R and B35-R label are presented in Fig.9.

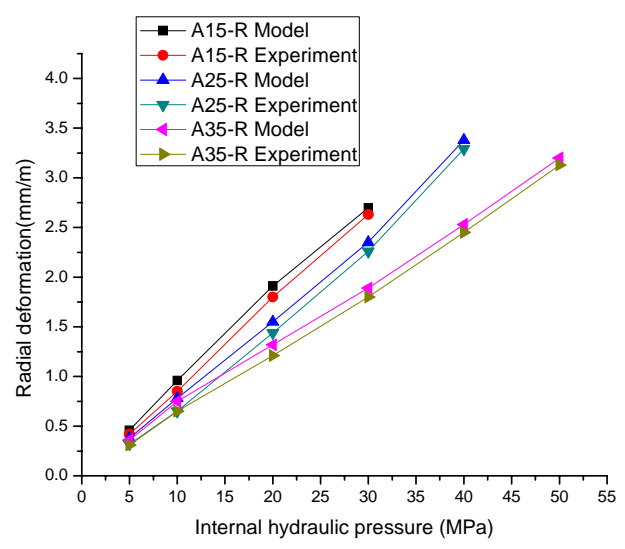

Figure 8. Radial deformations for multilayer tubes A15-R, A25-R and A35-R determined by experiment and by model

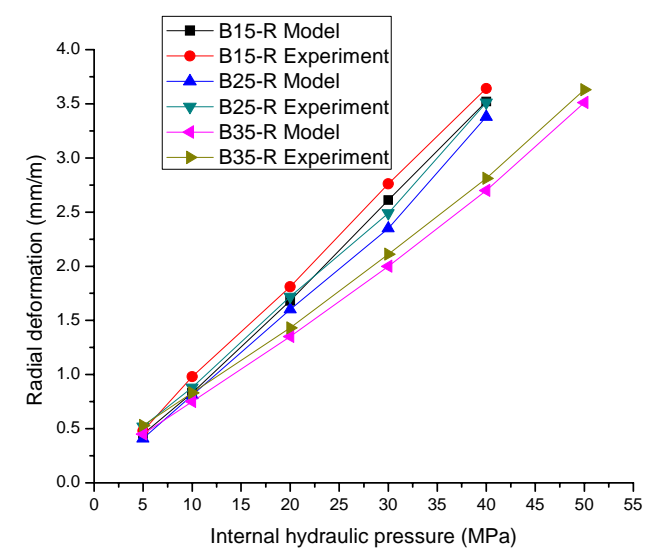

Figure 9. Radial deformations for multilayer tubes B15-R, B25-R and B35-R determined by experiment and by model

Values of the radial deformation at the elastic limit by experiment and the radial deformation at the elastic limit by model for multilayer tube of C15-R, C25-R and C35-R label are presented in Fig.10.

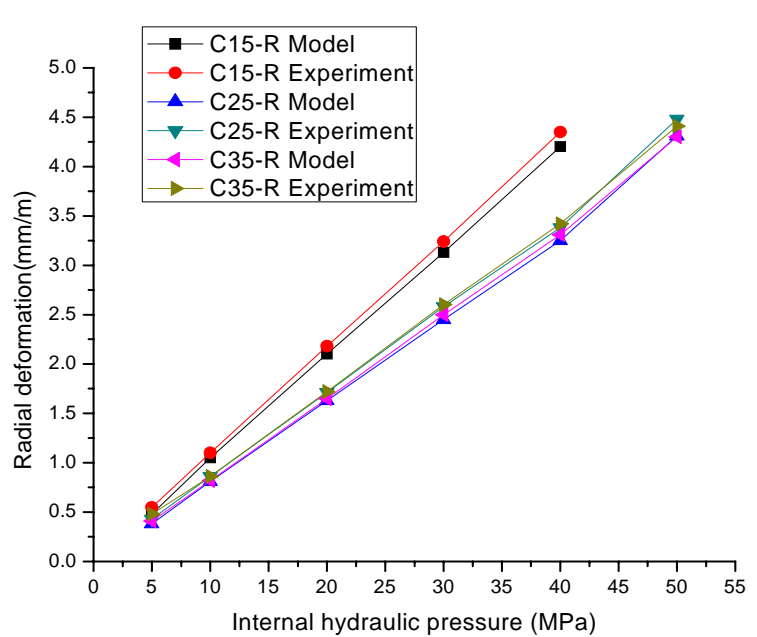

Figure 10. Radial deformations for multilayer tubes C15-R, C25-R and C35-R determined by experiment and by model

By comparasion of the experimentally determined values of the radial deformations at the elastic limit and values of the radial deformations at the elastic limit, obtained by the mentioned calculation of a simplified model, presented in Figures 8-10, a good agreement of these two parameters for all envisaged multilayer tubes metal liner/polymer composite can be seen.

Final characteristics of multilayer tubes metal liner/polymer composite, which were exposed to the influence of internal hydraulic pressure, i.e. values of hydraulic pressure and radial deformation at the burst moment of the mentioned tubes, are presented in Table 3.

Table 3. Hydraulic pressure and radial deformation at the burst moment of multilayer tubes metal liner/polymer composite

\begin{tabular}{|c|c|c|c|c|c|c|c|c|c||}
\hline \hline $\begin{array}{c}\text { Multilayer } \\
\text { tube label }\end{array}$ & A15-R & A25-R & A35-R & B15-R & B25-R & B35-R & C15-R & C25-R & C35-R \\
\hline \hline $\begin{array}{c}\text { Hydraulic } \\
\text { pressure at the } \\
\text { burst moment } \\
(\mathrm{MPa})\end{array}$ & 76.4 & 80.4 & 85.1 & 80.8 & 84.9 & 86.6 & 84.3 & 88.4 & 90.4 \\
\hline $\begin{array}{c}\text { Radial defor- } \\
\text { mation at the } \\
\text { burst moment } \\
(\mathrm{mm} / \mathrm{m})\end{array}$ & 12.25 & 12.75 & 13.25 & 11.00 & 11.25 & 11.45 & 12.25 & 12.90 & 13.25 \\
\hline
\end{tabular}

The smallest value of hydraulic burst pressure has a multilayer tube with type A metal liner (the most acute pathway from one to another external diameter of metal part) and metal liner wall of $1.5 \mathrm{~mm}$ thickness (76.4 MPa).

The highest value of hydraulic burst pressure has the multilayer tube with type $\mathrm{C}$ metal liner (the slightest pathway from one to another external diameter of metal part) and with $3.5 \mathrm{~mm}$ metal liner wall thickness (90.4 MPa).

Within one liner type, hydraulic burst pressure of the multilayer tubes metal liner/polymer composite slowly increases with increasing a wall thickness of the metal part.

The smallest value of the radial deformation at the burst moment (in the further text: final radial deformation) has a multilayer tube with type B liner (pathway from one to another external diameter of metal liner is at angle of $60^{\circ}$ ) and metal part wall thickness of $1.5 \mathrm{~mm}(11.00 \mathrm{~mm} / \mathrm{m})$.

The highest values of the final radial deformation has a multilayer tube with type $\mathrm{C}$ liner (pathway from one to another external radius of metal liner is at angle of $10^{\circ}$ ) and metal part wall thickness of $3.5 \mathrm{~mm}(13.25 \mathrm{~mm} / \mathrm{m})$.

Multilayer tubes with type B liner have smaller final radial deformations than multilayer tubes with type $\mathrm{A}$ and multilayer tubes with type $\mathrm{C}$ liner, which have a parameter 
quite similar to this one.

Mass values of the multilayer tubes metal liner/polymer composite, after machining outer surface of wound and cured composite part, are presented in Table 4.

Table 4. Mass of the multilayer tubes metal liner/polymer composite after machining of outer surface of composite part

\begin{tabular}{||c|c|c|c|c|c|c|c|c|c||}
\hline \hline $\begin{array}{c}\text { Multilayer } \\
\text { tube label }\end{array}$ & A15-R & A25-R & A35-R & B15-R & B25-R & B35-R & C15-R & C25-R & C35-R \\
\hline \hline $\begin{array}{c}\text { Multilayer } \\
\text { tube mass } \\
(\mathrm{g})\end{array}$ & 6956 & 7561 & 8175 & 6910 & 7542 & 8162 & 7506 & 8039 & 8562 \\
\hline
\end{tabular}

Calculated mass of entirely metal tube $500 \mathrm{~mm}$ long, with an internal diameter $119 \mathrm{~mm}$ and external diameter $132 \mathrm{~mm}$, is $10069 \mathrm{~g}$.

By comparing the mass of entirely metal tube with the above stated dimensions, and masses of the multilayer tubes (which have the same dimensions as metal tube) in which a part of metal tube is replaced with a composite part, it can be seen that mass reduction is from $15 \%$ (for multilayer tube of C35-R label) to $31 \%$ (for multilayer tube of B15-R label).

A parameter which represents a relation between hydraulic burst pressure (shortly, for the purpose of a tabular presentation: H.B.P.) and a mass of multilayer tube metal liner/polymer composite, is introduced in the analysis of the obtained data. Values of this parameter are presented in Table 5 .

Table 5. Values of a relation between hydraulic burst pressure and mass of multilayer tube metal liner/polymer composite

\begin{tabular}{|c|c|c|c|c|c|c|c|c|c|}
\hline $\begin{array}{c}\text { Multilayer } \\
\text { tube label }\end{array}$ & A15-P & A25-P & A35-P & B15-P & B25-P & B35-P & C15-P & C25-5 & C35-P \\
\hline $\begin{array}{c}\text { H.B.P./Mass } \\
\text { multilayer } \\
\text { tube (MPa/kg) }\end{array}$ & 11.0 & 10.6 & 10.4 & 11.7 & 11.2 & 10.6 & 11.2 & 11.0 & 10.6 \\
\hline
\end{tabular}

The highest value of this parameter has a multilayer tube label B15-R (11.7 MPa/kg), i.e. a tube which consist of metal liner of B type with $1.5 \mathrm{~mm}$ wall thickness (the smallest of the three used wall thicknesses of the metal part) and polymeric composite of $5 \mathrm{~mm}$ thickness (the highest of the three used thicknesses of the composite part).

The smallest value of this parameter has a multilayer tube label A35-R (10.4 MPa/kg), i.e. a tube which consists of the metal liner of A type with $3.5 \mathrm{~mm}$ wall thickness (the highest of the three used wall thicknesses of the metal part) and polymeric composite of $3 \mathrm{~mm}$ thickness (the smallest of the three used thicknesses of the composite part).

Multilayer tubes, which consist of $1.5 \mathrm{~mm}$ wall thickness metal liners (A15-R, B15-R and C15-R), have a value of this parameter 11 and more, which points out to positive influence of a higher presence of polymeric composite material on hydraulic burst pressure (increasing) and mass (decreasing) of the tested tubes.

On the other hand, multilayer tubes, which consist of 3.5 $\mathrm{mm}$ wall thickness metal liner (A35-R, B35-R and C35-R), i.e. metal parts with the highest wall thickness and polymeric composite parts with the smallest thickness (3 $\mathrm{mm}$ ), have the smallest value of this parameter (around 10.5), which points out to negative influence of a higher presence of metal material on hydraulic burst pressure (decreasing) and mass (increasing) of the tested tubes.

Liners of B type, regarding the liners of A type and liners of $\mathrm{C}$ type, have higher values of this realation, for a single liner of an appropriate wall thickness.

\section{Conclusions}

Based on everything written above, the following may be concluded:

1. Multilayer tubes consisting of the metal liner (produced by standard machining procedures using steel material) and polymer composite (produced by filament winding technology using glass fiber impregnated by polyester resin) were manufactured.

2. For a manufacturing of multilayer tubes three metal liner types (differing in a pathway from one to another external diameters) with three different wall thicknesses (overall nine versions) were used.

3. Multilayer tubes were exposed to the action of internal hydraulic pressure and during this test radial deformations and pressure were recorded from the initial moment to the burst moment of the mentioned tubes.

4. Based on the recorded data, a value of the experimental pressure at the elastic limit for multilayer tubes metal liner/polymer composite was determined.

5. Based on a simplified model of the multilayer tubes metal liner/polymer composite, a value of calculated pressure at the elastic limit was obtained.

6. There is a good agreement between experimentally determined pressure at the elastic limit and the calculated parameter, for the mentioned tubes.

7. Dependence of the internal hydraulic pressure - radial deformation, based on the experimentally recorded data multilayer tubes, are similar to dependence of the internal hydraulic pressure - radial deformations, based on the calculation procedure of a simplified multilayer tube model.

8. Considering only the number values, the hydraulic burst pressure $(76.4 \mathrm{MPa})$ has a multilayer tube with liner of A type and metal part wall thickness of $1.5 \mathrm{~mm}$ and polymer composite part thickness of $5 \mathrm{~mm}$, while the multilayer tube with metal liner of $\mathrm{C}$ type and metal part wall thickness of $3.5 \mathrm{~mm}$ and polymer composite wall thickness of $3 \mathrm{~mm}$ posses the highest value of this property (90.4 MPa).

9. Nominally, the highest final radial deformations (13.25 $\mathrm{mm} / \mathrm{m}$ ) has a multilayer tube with metal liner of C type and metal part thickness of $3.5 \mathrm{~mm}$ and polymer composite wall thickness of $3 \mathrm{~mm}$ and the smallest final radial deformations $(11.00 \mathrm{~mm} / \mathrm{m})$ are recorded at the multilayer tube with metal liner of B type and metal part wall thickness of $1.5 \mathrm{~mm}$ and polymer wall thickness of $5 \mathrm{~mm}$.

10. Regarding the entirely metal tube mass, replacing a part of the metal tube with filament wound glass fiber/polyester resin composite part reduces the mass from $15 \%$ to $31 \%$, depending on the metal liner type.

11. For specific purposes it is much convenient to use a parameter that represents the relationship between hydraulic burst pressure and mass of multilayer tubes.

12. Considering hydraulic burst pressure/mass ratio, it can be stated that a multilayer tube consisting of metal liner of B type with $1.5 \mathrm{~mm}$ metal part wall thickness (the smallest of the three used wall thicknesses of the metal part) and polymer composite part of $5 \mathrm{~mm}$ wall thickness (the highest of the three used thicknesses of the composite part) has the highest value of this parameter (11.7 $\mathrm{MPa} / \mathrm{kg}$ ). This fact points out to the positive effect of a higher presence of polymer composite material on hydraulic burst pressure (increasing) and mass (decreasing) of the mentioned multilayer tube. 
13. It is obvious that multilayer tubes with $3.5 \mathrm{~mm}$ wall thickness metal liner (not regarding the liner type) and $3 \mathrm{~mm}$ wall thickness polymeric composite have the smallest value of the mentioned parameter (around $10.5 \mathrm{MPa} / \mathrm{kg}$ ). Based on this statement, it can be observed that a higher presence of metal material has negative influence on hydraulic burst pressure (decreasing) and mass (increasing) of the mentioned multilayer tubes.

\section{Literature}

[1] GROOVER,M.P.: Fundamentals of Modern Manufacturing, Materials, Processes and Systems, John Wiley and Sons Inc., Hoboken, 2010, ISBN 978-0470-467008.

[2] TAI,Y.S., HUANG,M.Y., HU,H.T.: Numerical Modeling of SteelComposite Hybrid Tubes Subject to Static and Dynamic Loading, International Journal of Civil, Environmental, Structural, Construction and Architectural Engineering, 2012, Vol.6, No.5, pp.374-381.

[3] BAMBACH,M.R.: Axial capacity and crushing of thin-walled metal, fibre-epoxy and composite metal-fibre tubes, Thin Wall Structures; 2010, Vol.48, No.6, pp.440-452.

[4] CHOQUEUSE,D., BIGOURDAN,B., DEUFF,A., QUÉTEL,L.: Hydrostatic compression behaviour of steel-composite hybrid tubes, Conference Paper ICCM17 - The 17th International Conference on Composite Materials, July 2009, Edinburgh (UK).

[5] TZENG,J.T.: Dynamic Fracture of Composite Gun Tubes, Weapons and Materials Research Directorate, Army Research Laboratory-TR1869, January 1999.
[6] HIGH STRENGTH PIPING: Composite/steel pipe designed for extended service in hostile conditions, http://www.offshoremag.com/articles/print/volume-61/issue-3/news/high-strengthpiping-composite-steel-pipe-designed-for-extended-service-inhostile-conditions.htm

[7] POLYMER COMPOSITES: Volume 1, First Edition, Edited by Sabu Thomas, Kuruvilla Joseph, Sant Kumar Malhotra, Koichi Goda, and Meyyarappallil Sadasivan Sreekala. Published by WileyVCH Verlag GmbH \& Co. KGaA, 2012.

[8] RADULOVIĆ,J.: Filament Wound Composite Plastic Tubes: Relationship Between Winding Structures and Their Hydraulic and Mechanical Properties, Scientific Technical Review, ISSN 18200206, 2011, Vol.61, No.3-4, pp.73-77.

[9] KELly,A.: Concise Encyclopedia of Composite Materials, Pergamon Press, Oxford, 1989.

[10] RADULOVIĆ,J., ČITAKOVIĆ,S.: Mechanical Characteristics of Joints Between Glass Fiber Reinforced Composite Tubes and Steel Cylinder Obtained by Different Fastening Element, Scientific Technical Review, ISSN 1820-0206, 2016, Vol.66, No.2, pp.28-35.

[11] ROSATO,D.V.: Reinforced Plastics Handbook, 3Rd ed., Elsevier Advanced Technology Ltd., Oxford, 2004, ISBN 1856174506.

[12] RADULOVIĆ,J.: Thin Wall And Thick Wall Filament Wound Polymeric Composite Tubes: Mechanical Characteristics Caused by Internal Hydraulic Pressure, Scientific Technical Review, ISSN 1820-0206, 2013, Vol.63, No.1, pp.63-69.

[13] <ahRef="http://www.thefreedictionary.com/Hooke\%27s+law">Hoo $\mathrm{k}$ e's law $</ \mathrm{a}>$.

\title{
Polimerni kompozit/metal cilindri opterećeni iznutra: Izrada, ispitivanje i provera kvaliteta uprošćenim postupkom
}

\begin{abstract}
U ovom radu prikazani su detalji izrade višeslojnih cilindara koji se sastoje od metalnog lajnera (urađenih standardnim mašinskim postupcima) i polimernog kompozitnog materijala (urađenog tehnologijom mokrog namotavanja). Za izradu višeslojnih cilindara korišćena su tri tipa čeličnih lajnera (svaki lajner je imao tri različite debljine zida). Staklena vlakna impregnisana poliestarskom smolom su namotana sa spoljne strane pomenutih devet lajnera i ovako urađene višeslojne cevi su bile izložene dejstvu unutrašnjeg hidrauličkog pritiska uz merenje deformacija u radijalnom pravcu.

Prikazane su dve grupe rezultata, dobijenih za vreme hidrauličkih ispitivanja višeslojnih cevi : jednu grupu predstavljaju elastične karakteristike tj. osobine ispitivanih cevi na granici elastičnosti $i$ drugu grupu predstavljaju konačne karakteristike tj. osobine ispitivanih cevi u trenutku prskanja.

Izvršen je proračun pritiska na granici elastičnosti uproščenim postupkom. Poređenjem vrednosti eksperimentalno određenog pritiska na granici elastičnosti i izračunatog pritiska na granici elastičnosti, može da se zaključi da postoji dobro slaganje između ova dva podatka. Vrednosti eksperimentalno određenih radijalnih deformacija na spoljnoj površini višeslojnih cevi na granici elastičnosti i vrednosti ovog parametra, dobijenih proračunom uprošćenog modela su, takođe, značajno bliske.

Na osnovu eksperimentalnih podataka, utvrđen je uticaj prelaza sa manjeg spoljneg prečnika lajnera na veći spoljni prečnik lajnera i, takođe, uticaj debljine zida lajnera na karakteristike višeslojnih cevi, koje su bile izložene dejstvu unutrašnjeg hidrauličkog pritiska.

A na osnovu uvedenog parametra koji predstavlja odnos hidrauličkog pritiska prskanja i mase, zaključeno je da polimerni kompozitni materijal ima pozitivan uticaj na hidraulički pritisak prskanja (povećanje) i masu (smanjenje) navedenih višeslojnih cevi.
\end{abstract}

Ključne reči: polimerni materijali, kompozitni materijali, cilindar, cev, višeslojni element, stakleno vlakno, poliesterske smole, mokro namotavanje, hidraulični pritisak, elastične osobine, granica elastičnosti. 


\title{
Внутренне напряжённые полимерные композитные / металлические цилиндры: Производство, испытание и проверка качества упрощенной процедурой
}

\begin{abstract}
В этой статье представлены детали изготовления многослойных цилиндров, состоящих из металлического вкладыша (изготовленного стандартными машинными методами) и полимерного композитного материала (изготовленного по технологии мокрой обмотки). Для изготовления многослойных цилиндров использовались три типа стальных вкладышей (у каждого вкладыша были три разных толщины стенки). Стекловолокно, пропитанное полиэфирной смолой, было намотано снаружи вышеупомянутых девяти вкладышей, и, таким образом изготовленные многослойные трубы подвергались воздействию внутреннего гидравлического давления с измерением деформаций в радиальном направлении.

Здесь показаны два типа результатов, полученных при гидравлическом испытании многослойных труб: одну группу представляют упругие характеристики, т. е. свойства испытуемых труб́ на границе упругости и вторую группу представляют конечные характеристики, т.е. свойства испытуемых труб во время распыления.

Здесь тоже проведён расчёт давления на пределе упругости по упрощенной процедуре. Сравнивая значения экспериментально определённого давления на границе упругости и расчётного давления на границе упругости, можно сделать вывод, что между этими двумя данными существует хорошее согласие. Значения экспериментально определённых радиальных деформаций на внешней поверхности многослойных труб на границе упругости и значения этого параметра, полученные путём расчёта упрощенной модели, также значительно близки.

На основании экспериментальных данных было определено влияние перехода от меньшего внешнего диаметра вкладыша на более широкий внешний диаметр вкладыша, а также, влияние толщины стенки вкладыша на характеристики многослойных труб, которые подвергались действию внутреннего гидравлического давления. На основе введённого параметра, который представляет собой отношение гидравлического давления распыления и массы, сделан вывод о том, что полимерный композитный материал оказывает положительное влияние на гидравлическое давление распыления (увеличение) и на массу (уменьшение) упомянутых многослойных труб.
\end{abstract}

Ключевые слова: полимерные материалы, композитные материалы, цилиндр, труба, многослойный элемент, стекловолокно, полиэфирные смолы, мокрая обмотка, гидравлическое давление, эластичные характеристики, предел эластичности.

\section{Les cylindres métal / composite chargés de l’intérieur: fabrication, examen et vérification de la qualité par le procédé simplifié}

Les détails de la fabrication des cylindres composés du support en métal (produits par les procédés standard mécaniques) et du matériau polymère composite (produit par le filament enroulé) sont présentés dans ce papier. Pour la fabrication des cylindres à plusieurs couches on a employé trois types de support en acier (chaque support ayant trois différents épaisseurs de mur ).Les fibres en verre sont imprégnés par la résine polyester et enroulés de l'extérieur de neuf supports cités. Ces tubes à plusieurs couches ont été exposées à l'action de la pression hydraulique intérieure avec le mesurage des déformations dans la direction radiale.

On a présenté deux groupes de résultats obtenus pendant ces tests hydrauliques : un groupe présente les caractéristiques élastiques c'est-à-dire les propriétés des tubes examinés à ma limite d'élasticité ; la seconde groupe présente les caractéristiques finales c'est-à-dire les propriétés des tubes examinés au moment de l'éclat. On a calculé la pression à la limite d'élasticité par le procédé simplifié. Si l'on compare les valeurs de la pression déterminée expérimentalement à la limite d'élasticité avec la pression calculée à la limite d'élasticité on peut constater un bon accord entre ces deux données. Les valeurs des déformations radiales déterminées expérimentalement sur la surface extérieure des tubes à plusieurs couches à la limite d'élasticité et les valeurs de ce paramètre obtenues par le calcul du modèle simplifié sont également très approximatives.

A la base des données expérimentales on a établi l'influence du passage du diamètre extérieur plus petit au diamètre plus grand du support ainsi que l'influence de l'épaisseur du mur du support sur les caractéristiques des tubes à plusieurs couches exposés à l'action de la pression hydraulique intérieure. A la base du paramètre introduit qui représente le rapport entre la pression hydraulique de l'éclat et la masse on a conclu que le matériau composite polymère avait une influence positive sur la pression hydraulique de l'éclat (augmentation) et sur la masse (diminution) des tubes à plusieurs couches déjà cités.

Mots clés: matériaux polymères, matériaux composites, cylindre, tube, élément à plusieurs couches, fibre en verre, résine polyester, filament enroulé, pression hydraulique, caractéristiques élastiques, limite d'élasticité. 